International Journal of English Literature and Social Sciences
Vol-6, Issue-4; Jul-Aug, 2021
Journal Home Page Available: $\underline{\text { https://ijels.com/ }}$
Journal DOI: $10.22161 /$ ijels

Peer-Reviewed Journal

\title{
Texting and Chatting Styles of Grade 11 Students : A Case in the Philippines
}

\author{
Angieleen T. Ignacio ${ }^{1}$, Dr. Fhrizz S. De Jesus ${ }^{2}$
}

${ }^{1}$ Sto. Domingo National Trade School, Baloc, Talavera, Nueva Ecija, Philippines

${ }^{2}$ College of Management and Business Technology, Nueva Ecija University of Science and Technology, Palayan City, Philippines

Received: 11 Jun 2021; Received in revised form: 02 Jul 2021; Accepted: 14 Jul 2021; Available online: 26 Jul 2021

(C2021 The Author(s). Published by Infogain Publication. This is an open access article under the CC BY license

(https://creativecommons.org/licenses/by/4.0/).

\begin{abstract}
This study analyzed the text and chat messages of the students and its influences in students' written output/essay. Specifically, it analyzed the text and chat messages of the students as to style, word, formation, spelling, capitalization and punctuation and the significant relationship between text and chat messages. Also, it determined the influences of text and chat to the students' written outputs. This is a descriptive and qualitative study that made use descriptive and correlational design. It was conducted at So. Domingo National Trade School having 200 respondents who were in Grade 11. Data were gathered from the text messages and chats between the respondents and the researchers. Students' written outputs like essays was also gathered. Findings revealed that onomatopoeic spelling, and omitted apostrophes were mostly used by the respondents in text messages, while acronyms and initialisms, omitted apostrophes and emoticons were mostly present in their written outputs. There was also a negative trend of relationship between textism and written outputs. Therefore, textism did not affect the writing performance of the students.
\end{abstract}

Keywords—Text, Chat, Messages, Essay, Education

\section{INTRODUCTION}

With the advent of technological innovations and modernizations, things have been made easier to people especially in terms of communication. Undoubtedly, communication is, indeed, the greatest gift from God. Humans are born to express ideas, feelings, thoughts and ideas. Without communication, the world will be like a big round of chaos. According to Morgan (2015), man is a social being. This is the reason why humans have to get along with people every day. In fact, one of the axioms of human communication which gained prominence in all different fields states that "one cannot not communicate." This is one of the premises that lay the basis for the human communication theory expressed by its greatest exponent Watzlawick (1960). With this, people's way of communication changes through generation.

Undeniably, texting and chatting nowadays have become part of the common ways in order to communicate.
Lichauco (2017) writes, "This is the Philippines, the text messaging capital of the world, where SMS (Short Message Service) has given rise to a subculture with its own lingo, folklore and etiquette." Since almost everyone has gadgets, texting and chatting became a popular tool for Filipinos to keep in touch and to be updated about the issues and trends. President Benigno Aquino III, noted that Filipinos are among the most active texters in the world.

Today, survey shows about 400 million text messages are being sent by Filipinos every day or 142 billion a year. No wonder, the Philippines is known as the "texting capital of the world". And what is most surprising is that, nowadays, text messaging has taken communication to another level. It is always observable that most of the young generation, especially students, while talking, walking, eating, reading, even listening in classroom are continuously striking the keys of a device that seems to be a part of their hand, 
called cellphone, the most deliberate interactive media. There is indeed no doubt about this.

Apart from texting with the use of cell phone, people can also use other gadgets like laptops and computers through chatting. Aside from texting, Filipinos spend more time on social media than anyone else in the world. Filipinos spend an average of 4.17 hours daily on social media. Actually, fifty-eight percent of the Philippine population are active social media users on a monthly basis and the 15 th highest penetration rate in the world. No doubt Facebook has the greatest number of active monthly users with over one billion, followed by Facebook Messenger. This communication medium is used by more than 90 million active users every day for the purpose of communicating with others.

These cases are happening because Facebook is very much free to anyone who wants to join. People around the world chat with each other almost every day. Teachers and students chat with each other as well. And also, family members and friends chat with each other. Undeniably, people are enjoying the said application.

However, apart from the benefits of having cellular phones, laptops or computers mainly for speedy communication, these innovations are considered by some as a quandary to the English language learning of students specifically in terms of writing. Texting has evolved as a twenty-first-century phenomenon - as a highly distinctive graphic style, full of abbreviations and deviant uses of language, used by a young generation who does not care about standards.

Since, almost everyone was hooked in texting and chatting specifically the millennials, teachers more often than not, observed errors of the students when it comes to word and sentence construction. This is why, Lomas (2011) states that the birth of new words, and new meanings for existing words, are the most obvious signs of what technology has brought in linguistic terms. A significant number of new words are being driven into the language because of the increasingly pervasive role technology plays in people's lives.

Basically, when it comes to text messaging, chatting and vocabulary, there exists a particular relationship with these concepts since text messaging involves the use of language known as the "textese" or "textspeak." It is termed as the abbreviations and slang most commonly used due to the necessary brevity of mobile phone text messaging. Indeed, text-message or what Crystal (2014) also prefers to call 'textspeak' has become widespread and has become part of being existence around the globe.

In addition to this, Huang (2008) defines textese as a nascent dialect of English that subverts letters and numbers to produce ultra-concise words and sentiments which is indeed a horrifying language to loyalists and pedagogues. This strategy is being used by students nowadays especially, among the Senior High School students. Moreover, due to the excessive use of phones and other gadgets in texting and chatting, students, more often than not, use shortened language wherein single letters can replace words (see becomes $c$ ), single digits can replace words (for becomes 4), single letters or digits can replace a syllable (wait becomes w8), and word combinations can be shortened into a single or multiple words (you're becomes $u r)$.Apart from this, users are free to choose words that they are going to use, apply their own rules of capitalizations and punctuations and follow their own sentence construction. And because students are used to it, they sometimes apply it in the various writing activities done in school.

According to Rosen, Chang, Erwin, Carrier and Cheever (2010) such styles happened because texters need to conserve space resulting to the utilization of more abbreviations and otherwise shortening of words, dropping of letters, combining letters with symbols or numbers to make an appropriate sound, and even acronyms.

On the other hand, when it comes to Facebook chat, there exists a language called "netLingo." In the $21^{\text {st }}$ century, chatting became part of students because it involves students to student's interaction and teachers and students exchanging of information and documents, and can publish it on their wall or their online class groups. Acronyms have always been an integral part of computer culture, and they have spawned a new language on the internet.

There are thousands of terms that define the life online, including the largest list of chat styles and acronyms. Students often use unlike acronyms to cut the message they want to convey.

Recently, there have been growing concerns regarding the impact of net lingo on the English language. It has been said that the usage of net lingo is corrupting the standards of English (Johnston, 2003). Some educators even claimed that the drop in students' performance in English language papers could be caused by the prolonged use of net lingo (Teh, 2004). This claim seems justifiable as it is possible that frequent exposure to net lingo could lead to it being a habit. As such, students may unconsciously use net lingo in their academic writing.

In view of this, the DepEd has been emphasizing the importance of writing skills among the students. In fact, most of the subjects in Grade 11 such as English for Academic and Professional Purposes, Creative Nonfiction, Practical Research and Reading and Writing require students' mastery of the writing skills, preparing 
the students to be equipped in their work locally or globally with the various writing prompts were facilitated by the teachers. And as writing is involved, the set of rules, principles, and processes that govern the structure of sentences in a given language should be given much focus and consideration.

Senior High School students are, therefore, expected to produce error-free essays that demonstrate their understanding of the elements of writing. Students plan, draft, and complete written compositions on a regular basis, editing their essays for clarity, engaging language, and the correct use of standard American English.

Supposedly, Senior High School students should practice all forms of writing, with emphasis on writing coherence and focused essays that convey a well-defined perspective and good grammar. Indeed, it is very important for the students to master the skills in writing because it develops other skills with it. In fact, reading, speaking and even listening are taken into consideration. Development of the macro skills especially writing is one of the goals of the Department of Education. The realization of such goal lies in the hand of language teachers. That is why such mission cannot be realized if the writing skills and abilities of the students are being affected due to texting and chatting techniques and practices that they have.

Teachers really play an important role in developing the writing skills of the students. Teachers used classroom instructions and presentations to help the students learn and apply different concepts ( De Jesus, et.al, 2021). Nowadays, it is evident that students more often than not spend a lot of time holding their cellphones instead of paper and pen.

Thus, this research primarily sought to analyze the text and chat messages of the Grade 11 students of Sto. Domingo National Trade School. Also, it sought to determine the implications of text and chat messages on the students' written output/essay.

This study will be helpful among the language teachers to be aware on the common errors committed by the students and thus enable them to focus more on this aspect. They may also have the chance to innovate some strategies and techniques to develop the writing skills of the students even better. Lastly, it paves the way for them to utilize different writing prompts for the students.

\section{METHODOLOGY}

\section{a. Research Design}

This study used mixed method of research, qualitative and quantitative. One of the methods was the quantitative research which involves the collection of data so that information can be quantified and subjected to statistical treatment in order to support or refute alternate knowledge claims. The quantitative method was used to analyze the text and chat messages of the students in terms of style, word formation, spelling, capitalization and punctuation. It was also used to determine the significant difference between the text and chat messages of the students also in terms of style, word formation, spelling, capitalization and punctuation.

Qualitative research was also used in this study since it is a holistic approach that involves discovery. It is described as an unfolding model that occurs in a natural setting that enables the researchers to develop a level of detail from high involvement in the actual experiences (Creswell, 2008). Qualitative method was used to analyze the students' written outputs in terms of style, word formation, spelling, capitalization, punctuation and sentence construction in terms of grammar.

\section{b. Research Locale}

The research was conducted in Sto. Domingo National Trade School (SDNTS), Baloc, Nueva Ecija, Philiipines. The includes the Grade 11 learners of Sto. Domingo National Trade School in S.Y. 2017- 2018. The sample and sampling procedures were employed by the researchers.

\section{c. Sampling}

Purposive sampling was used to select the key participants. They were picked based on their expertise and the researchs' objectives. The participants were chosen based on their own experiences with the phenomenon. The total population of this study was 423 with a sample size of 200 . The researchers used Raosoft application with $94.8 \%$ confidence level and 5\% error of margin.

\section{d. Data Gathering}

The research instrument used was survey method and interview, wherein respondents answered questions administered through questionnaires and interviews.

The researchers' mentors double-checked the questionnaire after it was prepared using the data gathered. A pilot testing was conducted. The dependability coefficient of the instrument was calculated and found to be .906 suggesting that it has good internal consistency. The research instrument's validity was validated by submitting it to experts for comment, who gave it a 4.62 weighted mean and a verbal interpretation of "very good." The completed questionnaires were gathered after distribution, and the data was tallied for analysis.

The researchers personally administered the questionnaires to the student-respondents. The objectives of the study were clearly explained to respondents. The researchers 
clarified all the directions and all parts in the questionnaires in order to get their full cooperation as well as get just and objective results of the research.

After successfully answering the questionnaire, the researchers retrieved the all questionnaires to maintain the accuracy and validity of the results.

\section{e. Data Analysis}

The data gathered presented, analyzed and interpreted using frequency counts, percentage, weighted mean and Pearson R Correlation Analysis.

To describe the text and chat messages of the respondents, weighted mean was used and interpreted using a 5 point Likert scale.

To determine significant difference between text and chat message in terms of style, word formation, capitalization and punctuation, the researchers used the T-test of significant relationship.

All statistical computations were carried out using Microsoft excel and SPSS v.21

\section{RESULTS AND DISCUSSIONS}

\subsection{Analysis of Text and Chat Messages}

The text and chat messages of the students were analyzed based on the students' use of style, word formation, spelling, capitalization and punctuation. Samples of the students' text and chat messages were presented to identify the different practices that students utilized in texting and chatting.

\subsubsection{Text Messages}

Result shows that students often used onomatopoeic expressions with a weighted mean of 4.15. According to students, they often included these sounds to let their textmate/chatmate get connected to the story and to imagine what their experiences sound like. More so, these words add satisfaction to the chats and senders show their virtual presence in the visual form of communication.

These words gave an impression to the receiver of how the sender reacted to the text messages. This would also indicate that they are expressive of what they feel about certain issues. Moreso, onomatopoeia falls on the showing-saying continuum and involves elements of both showing and saying, contributing to relevance by providing direct evidence for some of the meaning it communicates. Students can better express themselves in text by using onomatopoeia in their conversation. (Wharton, 2009).
Table 1. Level of Usage of the Students' Text Messages as to Style

\begin{tabular}{|c|c|c|}
\hline FEATURES & $\begin{array}{l}\text { Weighted } \\
\text { Mean }\end{array}$ & $\begin{array}{l}\text { Verbal } \\
\text { Interpretation }\end{array}$ \\
\hline $\begin{array}{l}\text { Use code switching } \\
\text { (e.g. Where na you? for } \\
\text { Where are you?) }\end{array}$ & 3.71 & Often \\
\hline $\begin{array}{l}\text { Use gay lingo } \\
\text { (e.g., charot for it is just a } \\
\text { joke) }\end{array}$ & 3.04 & Sometimes \\
\hline $\begin{array}{l}\text { Use jejemon style } \\
\text { (e.g., jeje for laughing out } \\
\text { loud) }\end{array}$ & 2.53 & Seldom \\
\hline $\begin{array}{l}\text { Use colloquial/slang } \\
\text { words } \\
\text { (e.g., jowa for } \\
\text { girlfriend/boyfriend) }\end{array}$ & 3.08 & Sometimes \\
\hline $\begin{array}{l}\text { Use straight English } \\
\text { (e.g.,I am on my way friend) }\end{array}$ & 3.36 & Sometimes \\
\hline $\begin{array}{l}\text { Use my own choice of } \\
\text { words/ informal tone and } \\
\text { register } \\
(\text { e.g eow for hello })\end{array}$ & 3.02 & Sometimes \\
\hline $\begin{array}{l}\text { Use my own code/non- } \\
\text { conventional symbols } \\
(\text { e.g :); :]) }\end{array}$ & 3.20 & Sometimes \\
\hline $\begin{array}{l}\text { Use onomatopoeic } \\
\text { expression } \\
\text { (e.g hahaha, } \\
\text { grrrr,mwaaahh) }\end{array}$ & 4.15 & Often \\
\hline Overall Weighted Mean & 3.26 & Sometimes \\
\hline
\end{tabular}

Another style that students often used is the code switching with a weighted mean of 3.71 .

Code switching has been regarded by some members of the English Language Teachers (ELT) community as negative, undesirable behavior, "a failure or unwillingness to use and learn the target language", leading to a lowering of standards. Code switching thus far has for the most part not taken into account such factors as the nature of bilingualism in the community where the switching takes place, the relative status of the languages and other aspects of the social context. 
Students tend to translate whether Filipino or English as what happens due to lack of words. According to the students, if they do not know the equivalent English term of words/phrases they would translate it into Tagalog.

However, students sometimes used straight English (3.36); own code/non-conventional symbols (3.20) such as $w / c h$, $w /, \#, 0,:],: \mathrm{D}$ and \&; colloquial/slang words (3.08) such as mudra,; gay lingo (3.04) such as charr and churbabels; and their own choice of words/ informal tone and register (3.02) such as eow, low, gonna and wanna.

On the other hand, students seldom used jejemon style (2.53) in texting. Jejemon is defined by Urban Dictionary as one who has managed to subvert the English language to the point of incomprehensibility and who has developed their own language and written text.

This jejemon phenomenon is a style of writing shared among many teenagers in some social networks like Facebook. But according to the students, they seldom encountered textmate/chatmate who is a jejemon.

According to them, they often labeled jejemon as the people who are not attending schools. And although they always received text or chat messages from their classmates and relatives, they seldom encountered such text.

Based on the above-mentioned features, it clearly shows that students used the text messages style only for sometimes with a general weighted mean of 3.26. This happened because according to students, their style varied depending on who their textmates/chatmates are; and also depending on the topic.

\subsubsection{As to Word Formation}

Result revealed that students often clip words or shorten them with a weighted mean of 4.10. This happened because shortening of the words saves the sender the problem of possible mistakes with a complicated spelling, and, most importantly, contributes to the speed of message typing (Crystal 2008). From a sociolinguistic perspective, the usage of clippings is often restricted to a particular social group within a society.

In youth language, but also in expert language, the use of clippings displays a speaker's familiarity with the subject matter as well as it expresses and strengthens the speaker's belonging into a certain social group. Students also tend to clip words for speedy communication. They use such words as long as those are being understood by the one they are communicating with.

Furthermore, students also often used the initials/acronyms with a weighted mean of (4.02). Students used such acronyms in text messaging because these words are shorter. Common words that were used by the respondents were $S H S, S D N T S, C L S U, A U, B S E D, P U P$, IDK, SLR, AU, NEUST, JHS, SHS, BTW, ABM, STEM, HE, IA, TVL, CR and BTW.

Table 2. Level of Usage of the Students' Text Messages as to Word Formation

\begin{tabular}{|c|c|c|}
\hline FEATURES & $\begin{array}{l}\text { Weighted } \\
\text { Mean }\end{array}$ & $\begin{array}{l}\text { Verbal } \\
\text { Interpretation }\end{array}$ \\
\hline $\begin{array}{l}\text { Substitute the letter } z \\
\text { for } s \\
\text { (e.g., Alwayz for always) }\end{array}$ & 2.82 & Sometimes \\
\hline $\begin{array}{l}\text { Clip words or shorten } \\
\text { them } \\
\text { (e.g., Congrats for } \\
\text { congratulations) }\end{array}$ & 4.10 & Often \\
\hline $\begin{array}{l}\text { Join/compound two } \\
\text { words instead of } \\
\text { writing them separately } \\
\text { (e.g., somuch for so } \\
\text { much) }\end{array}$ & 3.06 & Sometimes \\
\hline $\begin{array}{l}\text { Shorten words by } \\
\text { omitting some letters } \\
\text { (e.g., goin'for going) }\end{array}$ & 3.28 & Sometimes \\
\hline $\begin{array}{l}\text { Use the } \\
\text { initials/acronyms } \\
\text { (e.g., GBU for God Bless } \\
\text { You) }\end{array}$ & 4.02 & Often \\
\hline $\begin{array}{l}\text { Duplicate/repeat the } \\
\text { word for emphasis } \\
\text { (e.g., ok ok for very } \\
\text { much okay) }\end{array}$ & 3.56 & Often \\
\hline $\begin{array}{l}\text { Coin words } \\
\text { (e.g., Xerox for } \\
\text { photocopy) }\end{array}$ & 3.44 & Sometimes \\
\hline $\begin{array}{l}\text { Use blended words } \\
\text { (e.g., brunch for } \\
\text { breakfast lunch) }\end{array}$ & 2.70 & Sometimes \\
\hline $\begin{array}{l}\text { Overall Weighted } \\
\text { Mean }\end{array}$ & 3.37 & Sometimes \\
\hline
\end{tabular}

Students prefer to use acronym or initialism for time saving purposes especially when the conversation involves the fast pace of turn taking. 
Also, students often duplicate/repeat the word for emphasis (3.56) students used very very, really really and so so. They did this thing to let the receiver know that the sender is very much certain about the text. They wanted the receiver of the message to remember the word they duplicated.

Apart from those cases, students sometimes coin words (3.44) such as lodi, shorten words by omitting some letters (3.28) such as goin, reviewin, and watchin; they join/compound two words instead of writing them separately (3.06) such as iknow, nomaam, and iwill; they substitute the letter $\mathrm{z}$ for s (2.82) such as alwayz, guyz, thiz, dayz and yez.; and lastly, they sometimes use blended words (2.70) such as mornight.

Based on the above-mentioned features, it clearly shows that students used the text messages according to word formation only for sometimes with a general weighted mean of 3.37. According to the students, these cases varied also depending on who their textmates/chatmates are and on the topic.

\subsubsection{As to Spelling}

Table 3. Level of Usage of the Students' Text Messages as to Spelling

\begin{tabular}{|l|l|l|}
\hline FEATURES & $\begin{array}{l}\text { Weight } \\
\text { ed } \\
\text { Mean }\end{array}$ & $\begin{array}{l}\text { Verbal } \\
\text { Interpretati } \\
\text { on }\end{array}$ \\
\hline $\begin{array}{l}\text { Omit or remove vowels } \\
\text { (e.g. pls for please) }\end{array}$ & 3.78 & Often \\
\hline $\begin{array}{l}\text { Assign a single letter or } \\
\text { number for particular words } \\
\text { (e.g., } \text { R for are, } \text { f for } \text { to) }\end{array}$ & 2.74 & Sometimes \\
\hline $\begin{array}{l}\text { Use symbol instead of words } \\
\text { (e.g. \# for number) }\end{array}$ & 2.56 & Seldom \\
\hline $\begin{array}{l}\text { Re-spell words for a more } \\
\text { straightforward sound } \\
\text { (e.g., Fone for } \text { phone) }\end{array}$ & 4.12 & Often \\
\hline $\begin{array}{l}\text { Reduplicate letters for } \\
\text { emphasis } \\
\text { (e.g. Soooooooo for so) }\end{array}$ & 3.60 & Often \\
\hline $\begin{array}{l}\text { Spell words as they are } \\
\text { pronounced which I } \\
\text { sometimes do in writing } \\
\text { words in school } \\
\text { (e.g., nid for need) }\end{array}$ & 2.61 & Sometimes \\
\hline $\begin{array}{l}\text { Mix numbers with letters in } \\
\text { writing words }\end{array}$ & 2.56 & Seldom \\
\hline
\end{tabular}

\begin{tabular}{|l|l|l|}
\hline $\begin{array}{l}\text { (e.g. L8er for later, w8 for } \\
\text { wait) }\end{array}$ & & \\
\hline $\begin{array}{l}\text { Use contraction } \\
\text { (e.g don't for do not) }\end{array}$ & 3.77 & Often \\
\hline Overall Weighted Mean & 3.22 & Sometimes \\
\hline
\end{tabular}

Table 3 shows the students often respelled words for a more straightforward sound with a weighted mean of $\mathbf{4 . 1 2}$ such as becoz, tnx, $f$, der, ur, kud, dtas, lab and dis. Students said that it is indeed easier to text if they will type word based on how it is read/pronounced. According to the students, they make sure that the words are still being understood by the receiver of their message.

Also students often omit or remove vowels with as weighted mean of $\mathbf{3 . 7 8}$ such as wnt, cn, stdy, wrng, tht and yrs. Removing vowels is a common feature of $\underline{\text { SMS }}$ language as it requires little cognitive effort to read, so it is often used where space is costly ( Thurlow, 2007). According to the students, they make sure that words are still readable and understandable.

Students also used contraction often with a weighted mean of 3.77 such as can't, don't, i'm, i've and didn't. In other words, the contraction shrinks the two words. So a contraction is just a word that is a shortened form of two words put together. Students used contraction for speedy communication and exchange of information.

Apart from this, students also often reduplicate letters for emphasis with a weighted mean of $\mathbf{3 . 6 0}$ such as yess, hellooo, pleassss, lifeeee, fineee, somedayyy, welcomeee and moreeee. Students did it this way when they wanted to emphasize a certain word. These words also include strong feeling towards the word being said.

Aside from these, students sometimes do the following: assign a single letter or number for particular words (2.74) such as 4, 2, and $\mathbf{u}$; and spell words as they are pronounced which they sometimes do in writing words in school (2.61) such as wud, weyt, mam, chus, wer, and taym. In this case, first and last letters were not changed for practical ease of use.

On the other hand, students seldom use symbols instead of words (2.56) such as ;), :] :(,\#,@ and :D. All of these refer to the status symbol of having social network awareness. Students also seldom mix numbers with letters in writing words (2.56) such as $\boldsymbol{w} 8 \mathbf{8 t}, 2$ day and un4gettable. According to the students, these cases sound like jejemon style so they seldom do this. Also, these may add a little burden to typing since mixing of numbers means clicking and changing the keypad from alphabet into numerical and symbol. 
Based on the above-mentioned features, it clearly shows that students used the text messages according spelling only for sometimes with a general weighted mean of 3.22. According to the students, these cases varied also depending on who their textmates/chatmates are; and also depending on the topic.

\subsubsection{As to Capitalization and Punctuation}

Students often overused punctuation marks with a weighted mean of 3.60. Common punctuation marks which were overused were comma ",,,", period" .....,", question mark "??????" and exclamation point"!!!!!!". According to the students since they are used to it, they kept on using punctuation marks regardless of their usage. Also, they think that these add effect to the message of their text. They also often do not use or they omit capitals with a weighted mean of 3.57. Based on the students' information, they tend not to capitalize anymore because this may also add additional burden because they still need to click the arrow to small and capital letter. Moreover, students also often use one/same punctuation mark to separate my messages with a weighted mean of 3.48. Same reason was applied just because they do not want to click another punctuation mark so when they used comma, this will be used to the whole text.

On the other hand, students sometimes resort to the following: overused capitals (3.20) such as STUDY, TOURISM, YES and MA'AM, ; started their message/sentence with a small letter (3.24); used the punctuation marks that they like (3.10); did not use or they omitted punctuation marks (3.06); and capitalized letters that they like (3.03). Based on the above-mentioned features, it clearly shows that students used the text messages according to capitalization and punctuation only for sometimes with a general weighted mean of $\mathbf{3 . 3 8}$. According to the students, these cases varied also depending on who their textmates/chatmates are; and also depending on the topic.

Table 4. Level of Usage of the Students' Text Messages as to Capitalization and Punctuation

\begin{tabular}{|l|l|l|}
\hline FEATURES & $\begin{array}{l}\text { Weighted } \\
\text { Mean }\end{array}$ & $\begin{array}{l}\text { Verbal } \\
\text { Interpretation }\end{array}$ \\
\hline $\begin{array}{l}\text { Omit or remove vowels } \\
\text { (e.g. pls for please) }\end{array}$ & 3.78 & Often \\
\hline $\begin{array}{l}\text { Assign a single letter or } \\
\text { number for particular } \\
\text { words } \\
\text { (e.g., } R \text { for are, } 2 \text { for } \text { to })\end{array}$ & 2.74 & Sometimes \\
\hline $\begin{array}{l}\text { Use symbol instead of } \\
\text { words }\end{array}$ & 2.56 & Seldom \\
\hline
\end{tabular}

\begin{tabular}{|l|l|l|}
\hline $\begin{array}{l}\text { (e.g. \# for number) } \\
\text { Re-spell words for a more } \\
\text { straightforward sound } \\
\text { (e.g., Fone for phone) }\end{array}$ & 4.12 & Often \\
\hline $\begin{array}{l}\text { Reduplicate letters for } \\
\text { emphasis } \\
\text { (e.g. Sooooooo for so) }\end{array}$ & 3.60 & Often \\
\hline $\begin{array}{l}\text { Spell words as they are } \\
\text { pronounced which I } \\
\text { sometimes do in writing } \\
\text { words in school } \\
\text { (e.g., nid for need) }\end{array}$ & 2.61 & Sometimes \\
\hline $\begin{array}{l}\text { Mix numbers with letters } \\
\text { in writing words } \\
\text { (e.g. L8er for later, w8 for } \\
\text { wait) }\end{array}$ & 2.56 & Seldom \\
\hline $\begin{array}{l}\text { Use contraction } \\
\text { (e.g don't for do not) }\end{array}$ & 3.77 & Often \\
\hline $\begin{array}{l}\text { Overall Weighted Mean } \\
\text { (e) }\end{array}$ & 3.22 & \\
\hline
\end{tabular}

As a result, it is clear that texters use excessively these new signs of communication styles which are considered for them as an effective tool to save time and avoid boredom.

This happened because students establish more diverse ways and varieties of expressions on the meaning and nature of message. These include pruning sentences for speedy interaction. It also conveys playful turn taking among the communicators.

Thus they believed that sentence structure is not important when texting because there is no such spelling and grammar rule when it comes to it as long as their message is being understood. They are free to use the style, word formation, spelling, capitalization and punctuations that they like.

\subsection{Chat Messages \\ 3.2.1 As to Style}


Table 5. Analysis of the Students' Written Output as to Style

\begin{tabular}{|c|c|c|}
\hline FEATURES & $\begin{array}{l}\text { Weighted } \\
\text { Mean }\end{array}$ & $\begin{array}{l}\text { Verbal } \\
\text { Interpretation }\end{array}$ \\
\hline $\begin{array}{l}\text { Use code switching } \\
\text { (e.g. Where na you? for } \\
\text { Where are you? I am } \\
\text { already here.) }\end{array}$ & 3.77 & often \\
\hline $\begin{array}{l}\text { Use gay lingo } \\
\text { (e.g.,charot for it is just a } \\
\text { joke) }\end{array}$ & 3.09 & Sometimes \\
\hline $\begin{array}{l}\text { Use jejemon style } \\
\text { (e.g., jeje for laughing out } \\
\text { loud) }\end{array}$ & 2.69 & Sometimes \\
\hline $\begin{array}{l}\text { Use colloquial/slang words } \\
\text { (e.g., jowa for } \\
\text { girlfriend/boyfriend) }\end{array}$ & 3.20 & Sometimes \\
\hline $\begin{array}{l}\text { Use straight English } \\
\text { (e.g.,I am on my way } \\
\text { friend) }\end{array}$ & 3.38 & Sometimes \\
\hline $\begin{array}{l}\text { Use my own choice of } \\
\text { words/ informal tone and } \\
\text { register } \\
\text { ( e.g eow for hello) }\end{array}$ & 2.86 & Sometimes \\
\hline $\begin{array}{l}\text { Use my own code/non- } \\
\text { conventional symbols } \\
(\text { e.g :), ;), : l) }\end{array}$ & 3.07 & Sometimes \\
\hline $\begin{array}{l}\text { Use onomatopoeic } \\
\text { expression } \\
\text { (e.g hahaha, } \\
\text { grrr,mwaahh })\end{array}$ & 4.13 & Often \\
\hline Overall Weighted Mean & 3.27 & Sometimes \\
\hline
\end{tabular}

Moreover, students sometimes used straight English own choice of words/ (3.38), colloquial/slang words such as puds, petmalu and werpa (3.08), gay lingo such as chaarr and charrot (3.09), own code/non-conventional symbols such as $2 k 17$ (3.07), and use their own choice of words/ informal tone and register such as kinda, gonna and wanna, (3.02). According to the students, these style varied based on the style of their textmates/chatmates.
Also students sometimes use jejemon style such as nope, hallu and elow (2.69). Compared to texting which is just seldom, this happened because according to the students, chatting is more informal than texting especially in case of group chat wherein anybody who is member can send and butt-in in the middle of conversation which makes the chat more informal, open and relaxed medium. It serves as an extension of verbal interaction as what is being sent.

Based on the above-mentioned features, it clearly shows that students used the text messages according to style only for sometimes with a general weighted mean of 3.27. According to the students, their chatting style varied depending on who their textmates/chatmates are; and depending on the topic.

Same reasons as to text are being mentioned by the students regarding their chat messages style. They also used onomatopoeic expression to express their feelings toward the messages sent.

Also, they used code switching if they lacked the equivalent words from English to Filipino and vice versa.

On the other hand, gay lingo was not evident, there is just one of which was used such as charrr. Also, jejemon style was not also used by the students only stayz,,dayz, alwayz and classmatez, were used. More so, it was observed that students follow most of the time the standard English. In fact, 88 of them indeed were able to finish their essay in English.

This also proves that although the students are very much hooked to text and chat messages, there all still some who followed the standard way in terms of writing. This is indeed a good motivation for teachers that they can still save the students from being much inclined with the text and chat messages practices that they have.

But there is just the use of informal language which is gonna and gehh. Students also did not use any colloquial or slang word. Codes were used such as $w /, w / c, 2 k 17$ and $24 / 7$, and $\&$.

Furthermore, onomatopoeic expressions were indeed observable such as ha-ha(10),boom (5),hehe (5), while others used yeh, tik-tak, grrrr, yehey, and wahaha.

\subsubsection{As to Word Formation}

Table 6 shows that, in terms of word formation, substitution with the letter $\mathrm{z}$ and $\mathrm{s}$ was observed such as stayz, dayz,alwayz, becauze and classmatez which also sounded as jejemon.

Students also clipped words on their essay such as mom (2), Dec. (3), Ms. (11), Mr.(3) and others used teen, $K$ pop, dad, ok, cause, camp and phone. Words are being combined as well such as ineedformy, sothat, inthe, 
inthat and iwant. There were also words shortened by omitting some letters such as cookin, and feelin.

More so, initial/acronyms were very much evident in the students' written output such as SHS (127), GSP (32), TV (5), SDNT(5), FB (2), NBA (2), LOL (2) and others used TC, MP, OK, OJT, BSP, GAS, JOLNHS, BTW, KJ, $O P M, G B U, M C$, and $C P$.

Table 6. Analysis of the Students' Written Outputs as to Word Formation

\begin{tabular}{|c|c|c|}
\hline FEATURES & $\begin{array}{l}\text { Weighted } \\
\text { Mean }\end{array}$ & $\begin{array}{l}\text { Verbal } \\
\text { Interpretation }\end{array}$ \\
\hline $\begin{array}{l}\text { Substitute the letter } z \\
\text { for } s \\
\text { (e.g., Alwayz for always) }\end{array}$ & 2.89 & Sometimes \\
\hline $\begin{array}{l}\text { Clip words or shorten } \\
\text { them } \\
\text { (e.g., Congrats for } \\
\text { congratulations) }\end{array}$ & 4.07 & Often \\
\hline $\begin{array}{l}\text { Join/compound two } \\
\text { words instead of } \\
\text { writing them separately } \\
(\text { e.g., Somuch for so } \\
\text { much) }\end{array}$ & 3.10 & Sometimes \\
\hline $\begin{array}{l}\text { Shorten words by } \\
\text { omitting some letters } \\
\text { (e.g., goin'for going) }\end{array}$ & 3.21 & Sometimes \\
\hline $\begin{array}{l}\text { Use the } \\
\text { initials/acronyms } \\
\text { (e.g., GBU for God Bless } \\
\text { You) }\end{array}$ & 3.48 & Often \\
\hline $\begin{array}{l}\text { Duplicate/repeat the } \\
\text { word for emphasis } \\
\text { (e.g., ok ok for very } \\
\text { much okay) }\end{array}$ & 3.98 & Often \\
\hline $\begin{array}{l}\text { Coin words } \\
\text { (e.g., xerox for } \\
\text { photocopy) }\end{array}$ & 3.49 & often \\
\hline $\begin{array}{l}\text { Use blended words } \\
\text { (e.g., brunch for } \\
\text { breakfast lunch) }\end{array}$ & 2.85 & Sometimes \\
\hline $\begin{array}{l}\text { Overall Weighted } \\
\text { Mean }\end{array}$ & 3.38 & Sometimes \\
\hline
\end{tabular}

\begin{tabular}{|l|l|l|}
\hline FEATURES & $\begin{array}{l}\text { Weighted } \\
\text { Mean }\end{array}$ & $\begin{array}{l}\text { Verbal } \\
\text { Interpretation }\end{array}$ \\
\hline $\begin{array}{l}\text { Omit or remove } \\
\text { vowels } \\
\text { (e.g. pls for please) }\end{array}$ & $\mathbf{3 . 7 6}$ & Often \\
\hline $\begin{array}{l}\text { Assign a single } \\
\text { letter or number for } \\
\text { particular words } \\
\text { (e.g., } \text { R for are, } 2 \text { for } \\
\text { to) }\end{array}$ & $\mathbf{2 . 7 3}$ & Sometimes \\
\hline $\begin{array}{l}\text { I use symbol instead } \\
\text { of words } \\
\text { (e.g. \# for number) }\end{array}$ & $\mathbf{2 . 6 1}$ & sometimes \\
\hline $\begin{array}{l}\text { Re-spell words for a } \\
\text { more } \\
\text { straightforward } \\
\text { sound } \\
\text { (e.g., Fone for } \\
\text { phone) }\end{array}$ & $\mathbf{4 . 1 1}$ & Often \\
\hline $\begin{array}{l}\text { Reduplicate letters } \\
\text { for emphasis } \\
\text { (e.g. Soooooooo for } \\
\text { so) }\end{array}$ & $\mathbf{3 . 6 6}$ & \\
\hline
\end{tabular}

There were also words being repeated/duplicated such as very very (15), thank you thank you (2) so so so (11), and others used have have, realy really, give give, enjoy enjoy, ever and ever, because because and go go go. There is just one word coined which is lodi. On the other hand, no blended words were used.

There were also words being repeated/duplicated such as very very (15), thank you thank you (2) so so so (11), and others used have have, realy really, give give, enjoy enjoy, ever and ever, because because and go go go. There is just one word coined which is lodi. On the other hand, no blended words were used.

\subsubsection{As to Spelling}

Table 7 shows that students often re-spell words for a more straightforward sound such as greyt, mam, wit, anfogetable, wer, and chus with a weighted mean of 4.11. Based on the students' word outputs, it is also indeed easier to chat if they will type word based on the easiest spelling possible. Students also often used contraction often such as can't, don't, I've, I'll and I'm with a weighted mean of 3.79. They really wanted to shorten the words because they send their chat message immediately.

Table 7. Level of Usage of the Students' Chat Messages as to Spelling 


\begin{tabular}{|l|l|l|}
\hline $\begin{array}{l}\text { Spell words as they } \\
\text { are pronounced } \\
\text { which I sometimes } \\
\text { do in writing words } \\
\text { in school } \\
\text { (e.g., nid for need) }\end{array}$ & $\mathbf{2 . 6 8}$ & Sometimes \\
\hline $\begin{array}{l}\text { Mix numbers with } \\
\text { letters in writing } \\
\text { words } \\
\text { (e.g. L8er for later, } \\
\text { w8 for wait) }\end{array}$ & $\mathbf{2 . 6 3}$ & sometimes \\
\hline $\begin{array}{l}\text { Use contraction } \\
\text { (e.g don't for do not) }\end{array}$ & $\mathbf{3 . 7 9}$ & Often \\
\hline $\begin{array}{l}\text { Overall Weighted } \\
\text { Mean }\end{array}$ & $\mathbf{3 . 2 4}$ & Sometimes \\
\hline
\end{tabular}

Also students often omit or remove vowels such as yt, hppy, scd, tchr and cht with a weighted mean of $\mathbf{3 . 7 6}$. Removing of vowels from certain words can still make their chat messages readable and understandable.

Lastly, they often reduplicate letters for emphasis such as yessss, maaaaam, hellooooo, thinkkkk and byeee with a weighted mean of 3.66. Students tend to do this for emphasis and to let the receiver of their chat message feel that they are certain about the said message.

In addition to these, students sometimes do the following: assign a single letter or number for particular words such as $\mathbf{u}, \mathbf{4}, \mathbf{2}, \mathbf{b}, \mathbf{d}$, and $\mathbf{c}(\mathbf{2 . 7 3})$; spell words as they are pronounced which I sometimes do in writing words in school such as always, rong, da, meni, lab, and hapi (2.68); mix numbers with letters in writing words (2.63); and use symbol instead of words such as $\boldsymbol{\&}$, w/ and w/c (2.61).

Students sometimes do these in chat unlike in texting as being mentioned above that in chat, students are very much free to use their styles, apply their own codes and strategies.

Based on the above-mentioned features, it clearly shows that students used the chat messages according to spelling only for sometimes with a general weighted mean of 3.24.

\subsubsection{As to Capitalization and Punctuation}

Table 8 shows that students often do not use/omit capitals such as shs, pangasinan, talavera, abm, manila and english with a weighted mean of (3.59). Same with texting, students tend not to capitalize anymore because this may also add additional burden because they still need to click the arrow to small and capital letters. Also students often overuse punctuation marks such as comma, period and exclamation point with a weighted mean of 3.57 .

According to the students since they are used to it, they keep on using punctuation marks regardless of their usage. Also they think that these add effect on the message of their chat. Moreover, students also often use one/same punctuation mark to separate my messages with a weighted mean of 3.44. Same reason is implied just because they do not want to click another punctuation mark so when they used comma, this will be used in the whole chat message.

On the other hand, students sometimes do the following: started their message/sentence with a small letter (3.29); use the punctuation marks that they like (3.20); overused capitals such as ACCOUNTANCY, STORAGE and EXPERIENCE (3.15); do not use/ omit punctuation marks (3.15); and capitalize letters that they like such as $M y$ UnForgetBle EXPerIEnce (3.00).

Based on the above-mentioned features, it clearly shows that students used the chat messages according to capitalization and punctuation only for sometimes with a general weighted mean of 3.30. According to the students, their chatting style varied depending on who their textmates/chatmates are; and depending on the topic.

Problems with capitalization and punctuation were also an issue on the conversation. Period and comma were used to separate one statement from the other but sometimes even these punctuation marks were no longer used. The word SHS was typed as $\boldsymbol{S h}$. The word $\boldsymbol{I}$ was typed as small letter $\boldsymbol{i}$. Capitalization was not applied properly in these cases. Too many asterisks and periods were also used. 
Table 8. Level of Usage of the Students' Chat Messages as to Capitalization and Punctuation

\begin{tabular}{|c|c|c|}
\hline FEATURES & $\begin{array}{l}\text { Weighted } \\
\text { Mean }\end{array}$ & $\begin{array}{l}\text { Verbal } \\
\text { Interpretation }\end{array}$ \\
\hline $\begin{array}{l}\text { Do not use or I omit } \\
\text { capitals } \\
\text { (e g. cabanatuan for } \\
\text { Cabanatuan) }\end{array}$ & 3.59 & Often \\
\hline $\begin{array}{l}\text { Overuse capitals } \\
\text { (e.g WHAT for What, } \\
\text { SEE YOU for See you) }\end{array}$ & 3.15 & Sometimes \\
\hline $\begin{array}{l}\text { Capitalize letters that I } \\
\text { like } \\
(\text { e.g I am SORRY for } \\
\text { bEinG LATE) }\end{array}$ & 3.00 & Sometimes \\
\hline $\begin{array}{l}\text { I started my } \\
\text { message/sentence with a } \\
\text { small letter } \\
\text { ( e.g okay I will be there } \\
\text { for Okay I will be there) }\end{array}$ & 3.29 & Sometimes \\
\hline $\begin{array}{l}\text { Overuse punctuation } \\
\text { marks } \\
\text { (e.g. Really?!!!? for } \\
\text { Really?) }\end{array}$ & 3.57 & Often \\
\hline $\begin{array}{l}\text { I do not use or I omit } \\
\text { punctuation marks } \\
\text { (e.g. arent you happy for } \\
\text { aren't you happy?) }\end{array}$ & 3.15 & Sometimes \\
\hline $\begin{array}{l}\text { Use the punctuation } \\
\text { marks that I like } \\
\text { (e.g What is your } \\
\text { name,,how old are you) }\end{array}$ & 3.20 & Sometimes \\
\hline $\begin{array}{l}\text { Only use one/same } \\
\text { punctuation mark to } \\
\text { separate my messages } \\
\text { (e.g okay. I am coming } \\
\text { to your party.what time } \\
\text { it will start?) }\end{array}$ & 3.44 & Often \\
\hline Overall Weighted Mean & 3.30 & Sometimes \\
\hline
\end{tabular}

3.3 Significant difference between Text and Chat Messages

\section{3.1 As to Style}

The students' text and chat messages were compared based on the styles used.

Table 9 shows the test result of the significant difference between the text and chat messages of the students in terms of style. The absolute value of the computed $t$ value of -0.186 is less than the absolute value of the critical $t$, hence, there is enough statistical evidence to accept the null hypothesis. Therefore, there is no significant difference between the text and chat messages of the students in terms of style at $5 \%$ level of significance.

Table 9. Significant Difference between the Text and the Chat Message of the Students as to Style

\begin{tabular}{|l|l|l|}
\hline & Styles & Chatting \\
\hline & Texting & 3.27 \\
\hline Mean & 3.26 & 0.471 \\
\hline Variance & 0.424 & 200 \\
\hline Observations & 200 & \\
\hline Df & 397 & \\
\hline t Stat & -0.186 & \\
\hline P(T<=t) two-tail & 0.85 & \\
\hline t Critical two-tail & 1.966 & Accept Ho \\
\hline Decision & Not Significant \\
\hline Interpretation &
\end{tabular}

There was indeed a negative impact of text and chat as to style. It was very evident that the text and chat messages really affect the way students write.

In terms of expression, students used onomatopoeia in their essay especially when their message involves too much emotions to express their feelings. The use of the code switching was also evident.

It was observed that students used the equivalent Tagalog term when they do not know the English term. In this case, linguistic ability of the student suffers. Students are used to do this style in writing. Teacher must emphasize that they need to improve their vocabulary whenever they are writing so as to prevent them from code switching.

Language teachers indeed need to help the students to practice not to use such word into formal writing. Language teachers should always facilitate their students towards the proper way of writing so as to prevent these cases. 


\section{3.2 As to Word Formation}

Table 10. Significant Difference between the Text and the Chat Message of the Students as to Word Formation

\begin{tabular}{|l|l|l|}
\hline & \multicolumn{2}{|l|}{ Word Formation } \\
\hline & Texting & Chatting \\
\hline Mean & 3.370 & 3.381 \\
\hline Variance & 0.397 & 0.463 \\
\hline Observations & 200 & 200 \\
\hline Df & 396 & \\
\hline $\mathrm{t}$ Stat & -0.162 & \\
\hline $\mathrm{P}(\mathrm{T}<=\mathrm{t})$ two-tail & 0.871 & \\
\hline $\mathrm{t}$ Critical two-tail & 1.966 & \\
\hline Decision & Accept $\mathbf{H}_{\mathbf{o}}$ & \\
\hline Interpretation & Not Significant \\
\hline
\end{tabular}

Table 10 shows the test result of the significant difference between the text and chat messages of the students in terms of word formation. The absolute value of the computed $t$ value of -0.162 is less than the absolute value of the critical $t$, hence, there is enough statistical evidence to accept the null hypothesis. Therefore, there is no significant difference between the text and chat messages of the students in terms of word formation at $5 \%$ level of significance.

There was indeed a negative impact of text and chat as to word formation. It was very evident that the text and chat messages really affect the way students write.

Students used acronym/initialism. Learners, however, should be knowledgeable about the proper ways of using acronym and initialism because in this case they just use it everytime they wanted to do so. Students also used clippings in writing which also distorted the rule of formal writing. Also, reduplication was evident in the essay which should not be applied in formal writing.

Teachers should focus on such errors and provide constant practice among students in terms of formal writing so as to prevent such cases.

\section{3.3 As to Spelling}

Table 11 shows the test result of the significant difference between the text and chat messages of the students in terms of spelling. The absolute value of the computed $t$ value of -0.328 is less than the absolute value of the critical $t$, hence, there is enough statistical evidence to accept the null hypothesis. Therefore, there is no significant difference between the text and chat messages of the students in terms of spelling at 5\% level of significance.

There was indeed a negative impact of text and chat as to spelling. It was very evident that the text and chat messages really affect the way students write.

Contraction, reduplication of letters and spelling of words into a straightforward sound were very much evident in the students written output.

Students should understand that contraction is not applicable in formal/academic writing. It is only used in informal writing. Students may have this rule on their mind, but they still applied contraction because they are used to it. Students also were used to duplicating the letters of words. They tend to be playful with the words which also affect their linguistic ability. They should understand that formal writing is a serious way of writing.

Students also cannot practice spelling properly if they are used to spell words based on how they wanted. Constant practice in spelling should therefore be given emphasis.

Table 11. Significant Difference between the Text and the Chat Message of the Students as to Spelling

\begin{tabular}{|l|l|l|}
\hline & \multicolumn{2}{|l|}{ Spelling } \\
\hline & Texting & Chatting \\
\hline Mean & 3.215 & 3.243 \\
\hline Variance & 0.530 & 0.554 \\
\hline Observations & 200 & 200 \\
\hline Df & 398.000 & \\
\hline $\mathrm{t}$ Stat & -0.382 & \\
\hline $\mathrm{P}(\mathrm{T}<=\mathrm{t})$ two-tail & 0.703 & \\
\hline $\mathrm{t}$ Critical two-tail & 1.966 & \\
\hline Decision & Accept $\mathbf{H}_{\mathbf{0}}$ & \\
\hline Interpretation & Not Significant \\
\hline
\end{tabular}

\section{3.4 As to Capitalization and Punctuation}

Table 12 shows the test result of the significant difference between the text and chat messages of the students in terms of capitalization and punctuation. The absolute value of the computed $t$ value of -0.219 is less than the absolute value of the critical $t$, hence, there is enough statistical evidence to accept the null hypothesis. Therefore, there is no significant difference between the text and chat messages of the students in terms of capitalization and punctuation at $5 \%$ level of significance. 
There was indeed a negative impact of text and chat as to capitalization and punctuation. It was very evident that the text and chat messages really affect the way students write.

Table 12. Significant Difference between the Text and the Chat Message of the Students as to Capitalization and Punctuation

\begin{tabular}{|l|l|l|}
\hline & \multicolumn{2}{|l|}{$\begin{array}{l}\text { Capitalization and } \\
\text { Punctuation }\end{array}$} \\
\hline & Texting & Chatting \\
\hline Mean & 3.28 & 3.30 \\
\hline Variance & 0.487 & 0.529 \\
\hline Observations & 200 & 200 \\
\hline Df & 397 & \\
\hline t Stat & -0.219 & \\
\hline P(T<=t) two-tail & 0.827 & \\
\hline t Critical two-tail & 1.966 & \\
\hline Decision & Accept $\mathbf{H}_{\mathbf{0}}$ \\
\hline Significant & Not Significant \\
\hline
\end{tabular}

Students no longer applied the proper way of capitalization as they do not observe capitalization of words. Students were also not familiar about the other punctuation marks because they are using common punctuation marks. Also, they used such capitalization without a better understanding of their usage.

Students also tend to overuse punctuation marks which sometimes look like a signature mark on their written output. Students, therefore, should be knowledgeable that such doing is not applicable in formal writing.

\section{CONCLUSION}

The study determined the text and chat messages among Grade 11 Senior High School Students of Sto. Domingo National Trade School.

The questionnaire was categorized as to style, word formation, spelling, capitalization and punctuation.

Based from the above findings the following are recommended:

For the students, they must be aware of the difference between the informal and formal writing. They must be given clear point that their text and chat messages should not be applied in academic writing.

For the teachers, they must be aware of the errors committed by their students and apply necessary remediation towards the development of the students' writing skills. Also, they may strategize on the opportunity of involving technology in language teaching. Teachers must also focus on teaching students the grammar aspect which plays a vital role for the students to have wellconstructed sentences in their written outputs. They must also clarify awareness on the extent use and context of use of text and chat which calls for creativity but still students must be aware of the linguistic aspect in terms of writing. Furthermore, language teachers should instill in the mind of the students the clear distinction between formal and informal writing. Teachers should also give emphasis on grammar and linguistic aspect. Traditional way of teaching should be integrated with technological innovations.

Future Researchers may study about the other parameters used in this study. They may also analyze not only the text and chat but other styles millennial students are using nowadays. They may also have the deeper analysis on the other reasons of errors committed in writing.

\section{ACKNOWLEDGEMENTS}

The researchers would like to thank their families who provided so much provision and understanding in completion of this research paper.

\section{REFERENCES}

[1] Crystal, D. (2010). A Little Book of Language. Yale University Press

[2] De Jesus, F.S. and De Jesus, M.B. (2021) Spending Habits of Public School Teachers in Palayan City. Open Access Library Journal, 8: e6332. https://doi.org/10.4236/oalib.1106332

[3] Huang, L. (2008. Technology: textese may be the death of English. Retrieved August 25, 2017, from,http://www.newsweek.com/technology- textese-maybe-death-english-87727

[4] Lomas, N. (2011). From lolcat to textspeak: How technology is shaping our language. Retrieved October 10, 2017, from, http://www.zdnet.com/article/from-lolcat-totextspeak-how-technology-is-shaping-our-language/

[5] Lichauco,J. (2017). The Philippines: Texting capital of the world. Retrieved September 20, 2017 from https://www.textengine.info/blog/the-philippines-textingcapital-of-the-world

[6] Johnston, J. (2003, March 2). Teachers call for urgent action as pupils write essays in text-speak. Sunday Herald. Retrieved November 08, 2017, from http://www.sundayherald.com/ print31826

[7] Morgan,N.(2010. We Humans Are Social Beings - And Why That Matters For Speakers and Leaders. Retrieved August 14, 2017, from https://www.forbes.com/sites/nickmorgan/2015/09/01/wehumans-are-social-beings-and-why-that-matters-forspeakers-and-leaders/\#41418a176abd 
[8] Rosen, L.S., Chang, J., Erwin, L., Carrier, L.M. \& Cheever, N.A. (2010). The relationship between "textisms" and formal and informal writing among young adults. Communication Research, 37(3), 420-440. doi: 10.1177/0093650210362465

[9] Teh, E. H. (2004, January 25). Debate over influence of SMS lingo on students. Sunday Star, Ole Brats p. 3.

[10] Watzlawick, P., Beavin-Bavelas, J., Jackson, D. (1967). Some Tentative Axioms of Communication. In Pragmatics of Human Communication - A Study of Interactional Patterns, Pathologies and Paradoxes. W. W. Norton, New York. 